THE POLITICS OF METHOD IN THE HUMAN SCIENCES 
POLITICS, HISTORY AND CULTURE

A series from the International Institute

at the University of Michigan

Series Editors: George Steinmetz and Julia Adams

Series Editorial Advisory Board: Fernando Coronil

Mamadou Diouf, Michael Dutton, Geoff Eley,

Fatma Müge Göcek, Nancy Rose Hunt, Andreas Kalyvas, Webb Keane, David Laitin, Lydia Liu, Julie Skurski, Margaret Somers,

Ann Laura Stoler, Katherine Verdery,

Elizabeth Wingrove

Sponsored by the International Institute at the University of Michigan and published by Duke University Press, this series is centered around cultural and historical studies of power, politics, and the state-and the field that cuts across the disciplines of history, sociology, anthropology, political science, and cultural studies. The focus on the relationship between state and culture refers both to a methodological approach -the study of politics and the state using culturalist methods-and as a substantive one that treats signifying practices as an essential dimension of politics. The dialectic of politics, culture, and history figures prominently in all the books selected for the series. 


\section{THE POLITICS OF METHOD IN}

\section{THE HUMAN SCIENCES}

Positivism and Its Epistemological Others

GEORGE STEINMETZ, EDITOR

$+\sqrt{z_{2}}$

Duke University Press Durham/London 2005 
(C) 2005 Duke University Press

All rights reserved

Printed in the United States of America

on acid-free paper $\infty$

Typeset in Minion by Keystone Typesetting, Inc.

Library of Congress Cataloging-in-Publication Data appear on the last printed page of this book.

Portions of Webb Keane's essay originally appeared in "Self-Interpretation, Agency, and the Objects of Anthropology: Reflections on a Genealogy," Comparative Studies in Society and History 45, 2 (2003). Reprinted with the permission of Cambridge University Press.

Michael Dutton's essay originally appeared in $\mathrm{Ne}$ pantla 3, 3 (2002). Copyright Duke University Press.

Portions of William Sewell's essay originally appeared in "Whatever Happened to the 'Social' in Social History," in Schools of Thought: Twenty-Five Years of Interpretive Social Science, edited by Joan W. Scott and Deborah Keates. Copyright Princeton University Press, 2001. 